Zeszyty Naukowe Szkoły Głównej Gospodarstwa Wiejskiego w Warszawie

Problemy Rolnictwa Światowego tom 18 (XXXIII), zeszyt 3, 2018: 306-314 DOI: $10.22630 /$ PRS.2018.18.3.88

Mirosława Tereszczuk ${ }^{1}$

Instytut Ekonomiki Rolnictwa i Gospodarki Żywnościowej - Państwowy Instytut

Badawczy w Warszawie

\title{
Rynek mięsa wieprzowego w Polsce w obliczu afrykańskiego pomoru świń (ASF)
}

\section{The Pork Market in Poland in the Face of African Swine Fever (ASF)}

\begin{abstract}
Synopsis. Celem badania jest ocena oddziaływania wirusa afrykańskiego pomoru świń ASF (African Swine Fever) na rozwój i funkcjonowanie rynku mięsa wieprzowego w Polsce. Wirus ten pojawił się w Polsce w lutym 2014 roku u dzików, a następnie w lipcu 2014 roku u świń. Badanie obejmuje lata 2014-2018, czyli okres występowania wirusa ASF w Polsce. Do końca lipca 2018 roku odnotowano 182 przypadki ASF u świń i ponad 2,6 tysiąca u dzików w czterech województwach wschodniej i centralnej Polski, a największe skupisko tej choroby zlokalizowane jest w województwie lubelskim. Pojawienie się wirusa ASF negatywnie wpłynęło na rynek mięsa wieprzowego w Polsce, skutkując ograniczeniami w eksporcie tego mięsa, kosztami likwidacji ognisk choroby i bioasekuracji. Mimo tych trudności produkcja mięsa wieprzowego w Polsce w latach 2014-2018 odznaczała się tendencja wzrostowa, a eksport jedynie w pierwszym roku występowania ASF obniżył się, w kolejnych latach, w związku z dywersyfikacją rynków zbytu, odnotowano jego wzrost. Do badania zastosowano metodę opisową i proste analizy statystyczne.
\end{abstract}

Slowa kluczowe: ASF - afrykański pomór świń, rynek mięsa wieprzowego, eksport, Polska

\begin{abstract}
The aim of the study is to assess the impact of African swine fever virus (ASF) on the development and functioning of the pork market in Poland. This virus appeared in Poland in February 2014 in wild boars, and then in July 2014 in pigs. The study covers the years 2014-2018, the period of ASF virus in Poland. By the end of July 2018, there were 182 cases of ASF in pigs and over 2.6 thousand in wild boars in four provinces of eastern and central Poland, and the largest cluster of this disease is located in the Lublin province. The appearance of ASF virus has had a negative impact on the pork market in Poland, resulting in restrictions on the export of this meat, costs of eradication of outbreaks and biosecurity. Despite these difficulties, the production of pork at this time was characterized by an upward trend, while exports only in the first year of the ASF decreased, but in subsequent years, due to the diversification of markets, there was an increase in exports. The descriptive method and simple statistical analyzes were used for the study.
\end{abstract}

Key words: ASF - African swine fever, pork market, exports, Poland

JEL Classification: Q13, Q17, Q54

\section{Wstęp}

Polska jest liczącym się producentem i eksporterem mięsa wieprzowego w Unii Europejskiej. W 2017 roku była na czwartej pozycji wśród głównych unijnych producentów

\footnotetext{
${ }^{1}$ mgr, IERiGŻ-PIB, ul. Świętokrzyska 20, 00-002 Warszawa, e-mail: miroslawa.tereszczuk@ierigz.waw.pl; https://orcid.org/0000-0002-5891-9306
} 
wieprzowiny z 8,5\% udziałem za: Niemcami (23\%), Hiszpanią (18\%) i Francją (9\%) oraz szóstym eksporterem wewnątrzunijnym z 5,4 \% udziałem za: Niemcami (26\%), Hiszpanią (19\%), Holandią (12\%), Danią (11\%) i Belgią (10\%), zaś w eksporcie poza UE na piątej pozycji z 6,1\% udziałem za: Hiszpanią (25\%), Danią (19,5\%), Niemcami (19\%) i Holandią (9,5\%). W 2013 roku, tj. przed pojawieniem się ASF, Polska była na 3 pozycji w eksporcie pozaunijnym z 12\% udziałem, za Danią - 27\% i Niemcami - 18\% (Eurostat, 2018).

W związku z wystąpieniem wirusa ASF w Polsce, od lutego 2014 roku embargo na polską wieprzowinę i wyroby wieprzowe wprowadziły kraje Unii Celnej: Rosja, Białoruś, Kazachstan, a także Ukraina oraz Chiny, Japonia, Korea Płd., Tajwan, Singapur, Azerbejdżan i Gruzja. Zmieniło to diametralnie sytuację branży mięsnej w Polsce i wymusiło na wielu podmiotach $w$ niej funkcjonujących przekierowanie produkcji i zdywersyfikowanie rynków zbytu. Większość czołowych odbiorców polskiej wieprzowiny (Białoruś, Rosja, Japonia, Chiny, Ukraina), których udział w wartości eksportu w 2013 roku stanowił ponad 40\%, zaprzestało importu tego mięsa z Polski. Spowodowało to prawie 24\% spadek wpływów z eksportu mięsa wieprzowego w 2014 roku (Tereszczuk, 2015). Polscy przedsiębiorcy zmuszeni zostali do poszukiwania nowych rynków zbytu. W pierwszej kolejności polska wieprzowina przekierowana została na rynki krajów Unii Europejskiej, Hongkongu oraz Stanów Zjednoczonych Ameryki. Wirus ASF tylko w pierwszym roku występowania wpłynął negatywnie na eksport mięsa wieprzowego z Polski. W kolejnych latach, dzięki dywersyfikacji rynków zbytu, nastąpił wzrost sprzedaży zagranicznej tego gatunku mięsa. W latach 2014-2017 odnotowano blisko 40\% wzrost wpływów z eksportu mięsa wieprzowego (Ministerstwo Finansów, 2018).

\section{Materiał i metoda badań}

Celem badania jest ocena oddziaływania wirusa afrykańskiego pomoru świń ASF (African Swine Fever) na rozwój i funkcjonowanie rynku mięsa wieprzowego w Polsce. Ze względu na charakter badanego zjawiska, tj. występowanie wirusa afrykańskiego pomoru świń - ASF w Polsce i jego wpływ na sektor wieprzowiny, zastosowano metodę opisowa, wykorzystująca materiały zgromadzone przez odpowiednie instytucje i publikacje internetowe oraz prostą analizę statystyczną. Wykorzystano dane Głównego Inspektoratu Weterynarii (GIW), opracowania i dane Państwowego Instytutu Weterynaryjnego - PIB (PIW-PIB), a także dane dot. produkcji i eksportu mięsa wieprzowego w Polsce pochodzacce z baz danych Ministerstwa Rolnictwa i Rozwoju Wsi (MRiRW), Ministerstwa Finansów (MF), Instytutu Ekonomiki Rolnictwa i Gospodarki Żywnościowej - PIB (IERiGŻ-PIB) oraz Komisji Europejskiej (KE) i Eurostatu. Okres badawczy obejmuje lata 2014-2018.

\section{Afrykański pomór świń - ASF}

ASF - to bardzo groźna, zakaźna i zaraźliwa choroba świń o wysokim wskaźniku śmiertelności. Pojawiające się w jej przebiegu objawy kliniczne i zmiany selekcyjne wykazują duże podobieństwo do ostrej postaci pomoru klasycznego świń (Winiarczyk, Grądzki, 2002). Najbardziej podatne na nią są świnie domowe oraz dziki. Najczęstszym sposobem zakażenia zwierząt jest bezpośredni lub pośredni kontakt z zakażonymi zwierzętami (Główny Inspektorat Weterynarii, 2018). W przypadku terenów o wysokim 
zagęszczeniu gospodarstw utrzymujących świnie, rozprzestrzenianie się wirusa między gospodarstwami jest stosunkowo łatwe za pośrednictwem osób odwiedzjących gospodarstwo, jak również przez zakażoną paszę, wodę, wyposażenie oraz skarmianie zwierząt odpadami kuchennymi (Ministerstwo Rolnictwa..., 2017). Wirus ASF nie jest groźny dla ludzi. Powoduje jednak duże straty ekonomiczne kraju w którym występuje. Mimo kilkudziesięciu lat badań, nie udało się dotychczas opracować skutecznej szczepionki na zwalczenie tego wirusa (Pejsak, 2016). Jedną z metod walki z tą chorobą jest postępowanie administracyjne, czyli zabicie i utylizacja chorych i podejrzanych o zachorowanie zwierząt oraz nie dopuszczanie do jego dalszego rozprzestrzeniania się poprzez rygorystyczne przestrzeganie zasad bioasekuracji ${ }^{2}$ (Levis, Baker ..., 2011). Wokół stwierdzonego ogniska ASF wyznacza się obszar zapowietrzony (o promieniu co najmniej $3 \mathrm{~km}$ ) i obszar zagrożony (sięgający co najmniej $7 \mathrm{~km}$ poza obszar zapowietrzony). W obszarach tych obowiązują stosowne nakazy, zakazy i ograniczenia związane $\mathrm{z}$ przemieszczaniem świń, połączone $\mathrm{z}$ nadzorem nad stanem zdrowia zwierząt $\mathrm{w}$ tych obszarach (Afrykański..., 2016).

Wirus ASF po raz pierwszy został stwierdzony w 1920 roku w Afryce w Kenii. W Europie pojawił się W 1957 roku w Portugalii (1957,1960-1994, 1999), skąd rozprzestrzenił się na kolejne kraje europejskie: Hiszpanię (1960-1995), Francję (19641974, 1984), Włochy (1967-1978), Sardynię (1967- do dziś), Związek Radziecki (1977), Maltę (1978-1979), Belgię (1985), Holandię (1986). W tym samym okresie choroba ta wystapiła także w krajach Ameryki Środkowej i Południowej: Kuba (1971 i 1980), Dominikana i Brazylia (1978), Haiti (1979). Wszystkie te kraje, z wyjątkiem Sardynii, doprowadziły do eradykacji wirusa. Nowa era wirusa ASF rozpoczęła się w 2007 roku i trwa do chwili obecnej. W latach 2007-2008 ogniska ASF potwierdzone zostały na terenie Kaukazu oraz Federacji Rosyjskiej, a w kolejnych latach w Iranie (2009), na Ukrainie (2012) oraz w Białorusi (2013). W 2014 roku pierwsze przypadki ASF potwierdzono na terenie Unii Europejskiej: w styczniu 2014 roku na Litwie, a w lutym 2014 roku w Polsce. Jedną z głównych przyczyn przedostania się wirusa ASF do Polski były dziki, które przeniosły chorobę od padłych i zarażonych dzików oraz czynnik ludzki, tj. brak przestrzegania wymogów bioasekuracji (Niemczuk i in., 2018).

Od lutego 2014 roku do końca lipca 2018 roku na terenie Polski stwierdzono 182 ogniska ASF u świń i ponad 2,6 tysiąca przypadków u padłych dzików (Komunikaty GIW..., 2018). Pierwszy przypadek ASF u świń został potwierdzony przez Główny Inspektorat Weterynarii (GIW) w lipcu 2014 roku, kolejny w sierpniu tego samego roku, a trzeci w styczniu 2015 roku. Wszystkie trzy w województwie podlaskim. W 2016 roku stwierdzono 20 zachorowań u świń na ASF (18 - woj. podlaskie, 2 - mazowieckie). Największe natężenie rozprzestrzeniania się wirusa ASF w Polsce przypada na lata 2017 i 2018 (rys. 1). Oprócz wyżej wymienionych dwóch województw pojawił się on również w województwie lubelskim i warmińsko-mazurskim (tab. 1).

\footnotetext{
2 Bioasekuracja trzody chlewnej na poziomie ferm to zestaw praktycznych działań i środków, które są podejmowane, aby zapobiegać przedostawaniu się wirusa do budynków fermy oraz aby kontrolować rozprzestrzenianie się infekcji na terenie fermy. Celem programu bioasekuracji jest utrzymywanie zarazków chorobotwórczych poza obszarem fermy tak, aby stado nie było na nie narażone oraz minimalizowanie niekorzystnego oddziaływania na zdrowie świń patogenów o charakterze endemicznym.
} 


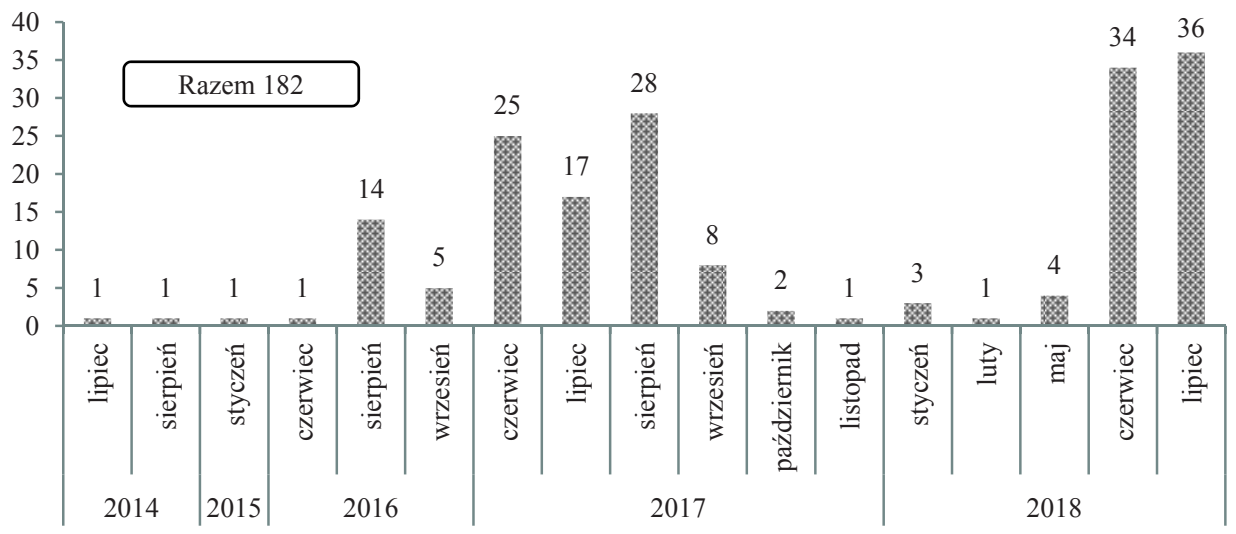

Rys. 1. Liczba zdiagnozowanych ognisk wirusa ASF u świń w poszczególnych miesiącach w latach 2014-2018

Fig. 1. The number of diagnosed ASF virus cases in pigs in particular months in 2014-2018

Źródło: opracowanie własne na podstawie komunikatów Głównego Inspektoratu Weterynarii (GIW).

Analiza sytuacji epizootycznej ASF w Polsce wskazuje na duże wahania liczby zdiagnozowanych ognisk wirusa u świń w poszczególnych miesiącach 2014-2018. Największe natężenie tej choroby odnotowano w okresie czerwiec-wrzesień 2017 roku i w analogicznym okresie 2018 roku (rys. 1). Może to mieć niekorzystny wpływ na stan pogłowia trzody chlewnej w kraju w kolejnych latach oraz utrudnienia w funkcjonowaniu firm mięsnych, łącznie $\mathrm{z}$ zaprzestaniem produkcji wieprzowiny. Alternatywą dla producentów żywca wieprzowego, rezygnujących z chowu trzody chlewnej może być przestawienie się na inne kierunki produkcji rolniczej (Alternatywą..., 2018).

Tabela 1. Liczba przypadków ASF u świń w poszczególnych województwach w latach 2014-2018

Table 1. Number of ASF cases in pigs in individual voivodships in 2014-2018

\begin{tabular}{|c|c|c|c|c|c|}
\hline \multirow{2}{*}{ Rok } & \multicolumn{5}{|c|}{$\begin{array}{c}\text { Liczba przypadków ASF } \\
\text { województwo }\end{array}$} \\
\hline & podlaskie & lubelskie & mazowieckie & $\begin{array}{l}\text { warmińsko- } \\
\text { mazurskie }\end{array}$ & Razem \\
\hline 2014 & 2 & - & - & - & 2 \\
\hline 2015 & 1 & - & - & - & 1 \\
\hline 2016 & 18 & - & 2 & - & 20 \\
\hline 2017 & 16 & 59 & 6 & - & 81 \\
\hline 2018 (do 31.07.2018) & 3 & 64 & 7 & 4 & 78 \\
\hline Razem & 40 & 123 & 15 & 4 & 182 \\
\hline
\end{tabular}

Źródło: opracowanie własne na podstawie komunikatów GIW.

W sytuacji wykrycia ogniska ASF w stadzie świń, wszystkie świnie w gospodarstwie muszą zostać humanitarnie uśmiercone i zutylizowane. Doprowadziło do zmniejszenia liczby producentów trzody chlewnej na terenie występowania wirusa ASF w województwach wschodniej Polski (podlaskie i lubelskie) o ok. 30\% (Szczepańska, 2018), tj. o ok. 8 tys. do ok. 19 tys. producentów (Charakterystyka..., 2017). Spośród tych 
województw w latach 2014-2016 spadek produkcji wieprzowiny odnotowano jedynie w województwie podlaskim gdzie najwcześniej pojawił się wirus ASF.

\section{Rynek mięsa wieprzowego w Polsce}

Polska jest jednym $\mathrm{z}$ większych producentów mięsa wieprzowego $\mathrm{w}$ Unii Europejskiej. Wieprzowina stanowi ok. 40\% całkowitej produkcji trzech podstawowych gatunków mięsa w Polsce (wieprzowina, wołowina i drób). Produkcja mięsa wieprzowego w Polsce w latach 2014-2017 odznaczała się tendencją wzrostową (Mroczek, 2018). W 2017 roku wyprodukowano 1894 tys. ton mięsa wieprzowego (bez podrobów) w wadze bitej ciepłej (w.b.c.) i było to o prawie $1 \%$ więcej niż rok wcześniej i o ok. $18 \%$ więcej niż w 2013 roku, tj. przed ASF. Również w pierwszym półroczu 2018 roku, mimo występowania ASF, utrzymywała się wzrostowa tendencja w produkcji mięsa wieprzowego w Polsce (rys. 2).

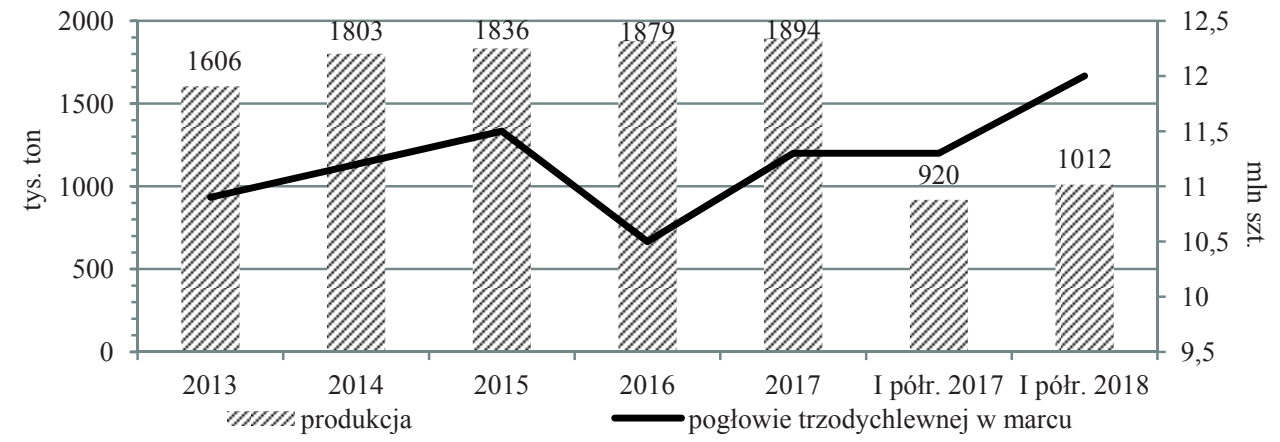

Rys. 2. Produkcja mięsa wieprzowego w Polsce w w.b.c. w tys. ton oraz pogłowie trzody chlewnej (stan w marcu) w mln sztuk

Fig. 2. Production of pork in Poland in p.s.w. in thous. tonnes and stock of pigs (as of March) in million pieces

Źródło: opracowanie własne na podstawie danych Głównego Urzędu Statystycznego (GUS).

Wstępne dane GUS o pogłowiu trzody chlewnej w Polsce w marcu 2018 roku wskazują (Biuletyn..., 2018), że zwiększyło się ono w porównaniu do analogicznego okresu 2017 roku o 6,5\% do blisko 12,0 mln sztuk, natomiast w porównaniu do marca 2014 roku wzrosło o 7,2\% (rys. 2). Największe „zagłębie” trzody chlewnej występuje w województwach: wielkopolskim, łódzkim i kujawsko-pomorskim. Przypada na nie blisko połowa produkcji żywca wieprzowego w Polsce i co istotne, są one wolne od wirusa ASF. W województwach, w których wystapily ogniska ASF, sytuacja przedstawia się następująco (tab. 2):

- w podlaskim, w marcu 2018 roku, pogłowie trzody chlewnej wyniosło 294,5 tys. sztuk i było niższe niż w analogicznym okresie 2014 roku o 12\%, tj. zmniejszyło się o przeszło 40 tys. sztuk,

- w lubelskim, pogłowie trzody chlewnej obniżyło się o przeszło 5\%, tj. o 30 tys. sztuk,

- w dwóch pozostałych województwach wzrosło, w warmińsko-mazurskim o prawie 7\%, zaś w mazowieckim o 34\% (Zawadzka i Pasińska, 2018). 
Spadek pogłowia w województwie podlaskim i lubelskim był wynikiem wygaszania produkcji przez drobnych producentów, hodujących po kilka świń i nie będących w stanie spełnić wymogów bioasekuracji.

Tabela 2. Pogłowie trzody chlewnej i produkcja żywca wieprzowego w wadze żywej (wg województw) Table 2. Pig population and live pig production in live weight (by voivodships)

\begin{tabular}{|c|c|c|c|c|c|c|c|c|}
\hline \multirow{3}{*}{ Wyszczególnienie } & \multicolumn{4}{|c|}{ Pogłowie } & \multicolumn{4}{|c|}{ Produkcja żywca wieprzowego } \\
\hline & \multicolumn{2}{|c|}{ marzec 2014} & \multicolumn{2}{|c|}{ marzec 2018} & \multicolumn{2}{|c|}{2014} & \multicolumn{2}{|c|}{2016} \\
\hline & tys. sztuk & $\begin{array}{c}\text { III } \\
2013=100\end{array}$ & tys. sztuk & $\begin{array}{c}\text { III } \\
2017=100\end{array}$ & tys. ton & $\begin{array}{c}\text { udział } \\
\text { w } \%\end{array}$ & tys. ton & $\begin{array}{c}\text { udział } \\
\text { w \% }\end{array}$ \\
\hline Polska & 11186,0 & 102,3 & 11992,2 & 106,5 & 2310,8 & 100,0 & 2409,8 & 100,0 \\
\hline Dolnośląskie & 162,9 & 77,1 & 207,6 & 105,9 & 20,9 & 0,9 & 23,2 & 1,0 \\
\hline Kujawsko-pomorskie & 1297,0 & 103,3 & 1247,9 & 101,7 & 290,8 & 12,6 & 297,7 & 12,4 \\
\hline Lubelskie & 568,5 & 101,8 & 538,5 & 87,2 & 152,9 & 6,6 & 162,3 & 6,7 \\
\hline Lubuskie & 154,9 & 105,5 & 166,3 & 99,4 & 32,6 & 1,4 & 33,8 & 1,4 \\
\hline Łódzkie & 970,9 & 100,1 & 1278,0 & 119,1 & 259,1 & 11,2 & 268,3 & 11,1 \\
\hline Małopolskie & 179,5 & 89,8 & 167,7 & 87,8 & 62,1 & 2,7 & 61,0 & 2,5 \\
\hline Mazowieckie & 941,3 & 100,6 & 1258,0 & 126,3 & 217,9 & 9,4 & 223,9 & 9,3 \\
\hline Opolskie & 424,9 & 102,5 & 395,0 & 99,4 & 72,3 & 3,1 & 60,3 & 2,5 \\
\hline Podkarpackie & 178,4 & 104,8 & 154,7 & 90,5 & 47,2 & 2,0 & 47,4 & 2,0 \\
\hline Podlaskie & 335,8 & 97,4 & 294,5 & 95,9 & 96,9 & 4,2 & 87,9 & 3,6 \\
\hline Pomorskie & 734,5 & 104,9 & 786,8 & 109,4 & 198 & 8,6 & 239,1 & 9,9 \\
\hline Śląskie & 242,2 & 97,8 & 228,1 & 96,4 & 56,2 & 2,4 & 51,0 & 2,1 \\
\hline Świętokrzyskie & 228,9 & 100,5 & 225,1 & 107,6 & 63,2 & 2,7 & 58,6 & 2,4 \\
\hline Warmińsko-mazurskie & 504,9 & 103,0 & 539,5 & 111,3 & 107,0 & 4,6 & 119,7 & 5,0 \\
\hline Wielkopolskie & 3959,7 & 105,0 & 4200,4 & 105,3 & 580,8 & 25,1 & 624,4 & 25,9 \\
\hline Zachodniopomorskie & 301,8 & 104,3 & 304,0 & 109,5 & 52,9 & 2,3 & 51,2 & 2,1 \\
\hline
\end{tabular}

Źródło: opracowanie własne na podstawie danych GUS (Rocznik Statystyczny Rolnictwa).

Udział produkcji mięsa wieprzowego w województwach dotkniętych ASF w produkcji krajowej tego mięsa w latach 2014-2016 był w miarę stabilny i wynosił ok. 25\%. Spadek odnotowano jedynie w województwie podlaskim (ok. 10\%), natomiast w pozostałych trzech województwach produkcja mięsa wieprzowego w analizowanym okresie wzrosła: w lubelskim o 6\%, mazowieckim o 3\%, zaś w warmińsko-mazurskim o 12\% (tab. 2).

Wzrost produkcji wieprzowiny w Polsce w latach 2014-2017 miał odzwierciedlenie w poprawie wyników handlu zagranicznego mięsem wieprzowym (rys. 3). Mimo trudności w eksporcie mięsa wieprzowego, wynikających z występowania w Polsce wirusa ASF i ograniczeń wprowadzonych przez kraje pozaunijne w formie embarga na polską wieprzowinę $^{3}$, eksport mięsa wieprzowego w ostatnich latach odznaczał się tendencją wzrostową, poza niewielkim spadkiem w 2014 roku. W 2017 roku wyeksportowano

${ }^{3}$ W lutym 2014 roku następujące kraje wprowadziły embargo na polską wieprzowinę: Federacja Rosyjska, Białoruś, Kazachstan, Chiny, Japonia, Korea Płd., Tajwan, Singapur, Azerbejdżan, Gruzja i Ukraina (regionalizacja). 
z Polski prawie 480 tys. ton mięsa wieprzowego, czyli o 9,5\% więcej niż rok wcześniej i o $25 \%$ więcej niż w 2014 roku (Tereszczuk, 2018).

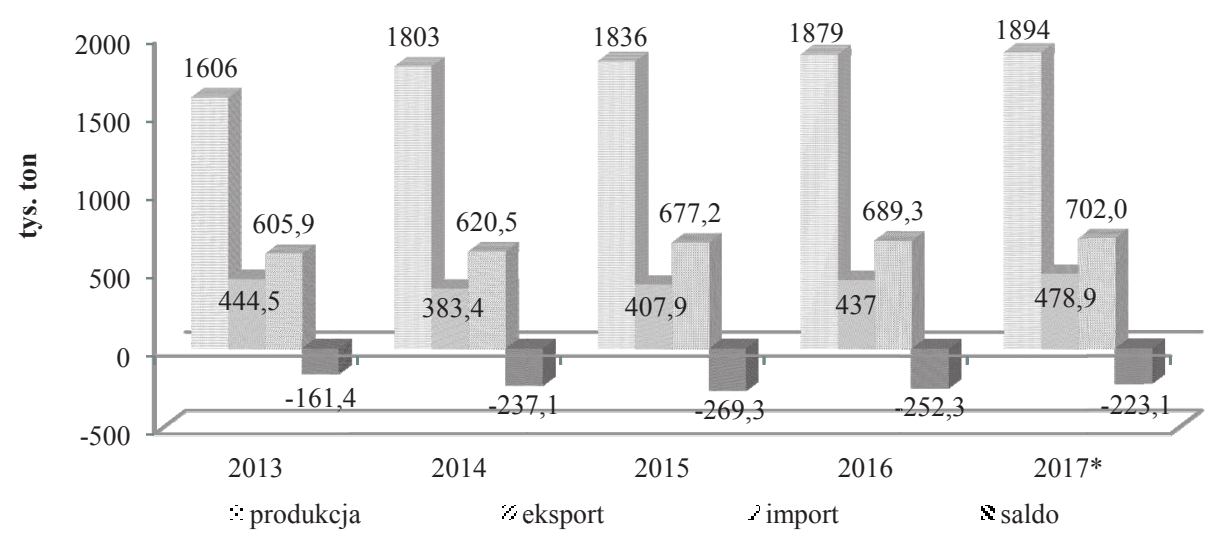

Rys. 3. Rynek mięsa wieprzowego w Polsce w latach 2013-2017 - produkcja mięsa wieprzowego w w.b.c. w tys. ton oraz handel zagraniczny mięsem wieprzowym w tys. ton (wagi żywej)

Fig. 3. Pork meat market in Poland in 2013-2017 - production of pork meat in p.s.w. in thous. tonnes and foreign trade in pork meat in thous. tonnes (live weight)

Źródło: opracowanie własne na podstawie danych GUS i Ministerstwa Finansów (MF).

Tabela 3. Główni odbiorcy mięsa wieprzowego (CN 0203) z Polski w latach 2013-2017

Table 3. Main recipients of pork (CN 0203) from Poland in 2013-2017

\begin{tabular}{|c|c|c|c|c|c|c|c|c|}
\hline \multicolumn{3}{|c|}{2013} & \multicolumn{3}{|c|}{2015} & \multicolumn{3}{|c|}{2017} \\
\hline Kraj & $\begin{array}{c}\text { Wartość } \\
{[\mathrm{mln}} \\
\text { EUR }]\end{array}$ & $\begin{array}{c}\text { Wolumen } \\
\text { [tony] }\end{array}$ & Kraj & $\begin{array}{c}\text { Wartość } \\
{[\mathrm{mln}} \\
\text { EUR] }\end{array}$ & $\begin{array}{l}\text { Wolumen } \\
\text { [tys. ton] }\end{array}$ & Kraj & $\begin{array}{c}\text { Wartość } \\
{[\mathrm{mln}} \\
\text { EUR] }\end{array}$ & $\begin{array}{l}\text { Wolumen } \\
\text { [tys. ton] }\end{array}$ \\
\hline OGÓŁEM & 925,1 & 444,5 & OGÓŁEM & 703,2 & 407,9 & OGÓŁEM & 965,5 & 478,9 \\
\hline w tym UE & 469,0 & 225,0 & w tym: UE & 572,0 & 336,8 & w tym: UE & 660,5 & 339,0 \\
\hline poza UE & 456,1 & 219,5 & poza UE & 131,2 & 71,1 & poza UE & 305,0 & 139,9 \\
\hline Białoruś & 104,5 & 42,5 & Włochy & 94,7 & 62,1 & USA & 176,9 & 58,6 \\
\hline Rosja & 99,4 & 35,8 & Czechy & 78,2 & 31,6 & Włochy & 98,5 & 59,4 \\
\hline Włochy & 82,4 & 43,4 & Słowacja & 72,3 & 38,3 & Niemcy & 96,0 & 70,4 \\
\hline Japonia & 75,8 & 24,8 & USA & 64,2 & 24,2 & Czechy & 76,7 & 28,4 \\
\hline Słowacja & 71,6 & 32,4 & Niemcy & 49,9 & 47,6 & Słowacja & 73,4 & 32,2 \\
\hline Czechy & 70,8 & 22,2 & W. Brytania & 36,0 & 14,4 & Hongkong & 47,9 & 34,6 \\
\hline Chiny & 67,5 & 51,7 & Litwa & 32,8 & 20,3 & W. Brytania & 45,7 & 17,4 \\
\hline Węgry & 57,4 & 27,3 & Łotwa & 32,7 & 16,7 & Rumunia & 38,1 & 18,7 \\
\hline Niemcy & 43,3 & 29,8 & Węgry & 30,8 & 17,9 & Litwa & 36,2 & 19,1 \\
\hline Ukraina & 33,0 & 19,3 & Hiszpania & 24,6 & 13,3 & Węgry & 34,6 & 15,0 \\
\hline
\end{tabular}

Źródło: opracowanie własne na podstawie danych MF. 
W związku z występującym w Polsce wirusem ASF i ograniczeniami w handlu zagranicznym mięsem wieprzowym z krajami pozaunijnymi, eksport tego mięsa został przekierowany do krajów UE-28. Spośród tych krajów najwięcej mięsa wieprzowego w 2017 roku sprzedano do: Niemiec (15\% wolumenu eksportu), Włoch $(12,4 \%)$ oraz Słowacji (7\%) i Czech (6\%). Natomiast z krajów pozaunijnych największym odbiorcą tego mięsa w 2017 roku były Stany Zjednoczone Ameryki (12\%) oraz Hongkong (7,2\%) (tab.3).

\section{Podsumowanie}

Od momentu wykrycia w Polsce pierwszego przypadku zachorowania na ASF (luty 2014 roku) minęły już cztery lata. W tym czasie odnotowano 182 ogniska ASF u świń i ponad 2,6 tys. przypadków tego wirusa u dzików w czterech województwach: podlaskim, lubelskim, mazowieckim i warmińsko-mazurskim. Około 8 tysięcy producentów rolnych z ww. województw zmuszonych zostało do rezygnacji z chowu świń z uwagi na trudności w sprzedaży zwierząt oraz spełnienia wymogów bioasekuracji, a także niską opłacalnością chowu trzody chlewnej. Jedną z alternatyw dla byłych producentów żywca wieprzowego jest przestawienie się na hodowlę bydła mięsnego (Alternatywą..., 2018). Jest to trudne, gdyż budynki oraz infrastruktura nie są do tego przystosowane.

Dalsze rozprzestrzenianie się wirusa ASF na inne województwa, zwłaszcza o dużej koncentracji produkcji żywca wieprzowego, oznaczać może pogorszenie wskaźnika samowystarczalności produkcji i w jeszcze większym stopniu uzależnienie się od importu mięsa wieprzowego.

Potwierdzenie wirusa ASF w Polsce, spowodowało, że wiele krajów pozaunijnych (Rosja, Białoruś, Ukraina (regionalizacja), Kazachstan oraz Chiny, Japonia i Korea Płd., Tajwan, Singapur, Azerbejdżan oraz Gruzja) zakazało importu produktów wieprzowych z naszego kraju. Spowodowało to trudności w eksporcie oraz konieczność zdywersyfikowanie rynków zbytu. Rok 2014 był najtrudniejszy dla sektora, gdyż polscy eksporterzy zmuszeni zostali do poszukiwania nowych rynków zbytu $\mathrm{w}$ krajach UE. W kolejnych latach eksport mięsa wieprzowego odznaczał się tendencją wzrostową, a głównym odbiorcą mięsa wieprzowego z Polski w 2017 roku były Stany Zjednoczone Ameryki.

Ponad cztery lata walki z ASF wskazują, że podjęte działania były niewystarczające i w niektórych przypadkach spóźnione. W związku z powyższym proces uwolnienia kraju od tego wirusa może być długotrwały i kosztowny. Bardzo ważne jest rygorystyczne przestrzeganie zasad bioasekuracji, na którą można uzyskać dofinansowanie z budżetu państwa (Agencja..., 2018). Ponadto na walkę z ASF w Polsce skierowane zostały środki finansowe $\mathrm{w}$ formie rekompensat $\mathrm{m}$.in. za rezygnacje $\mathrm{z}$ hodowli świń $\mathrm{w}$ rejonach występowania ASF oraz na zmianę profilu produkcji z chowu świń na rzecz bydła mięsnego.

\section{Literatura}

Afrykański pomór świń. Podstawowe fakty i informacje (African swine fever. Basic facts and information). (2016). Biuletyn Informacyjny MRiRW, 9, 5-10.

Agencja Restrukturyzacji i Modernizacji Rolnictwa. Pomoc krajowa. (Agency for Restructuring and Modernization of Agriculture. Domestic help). Pobrano sierpień 2018 z: http://www.arimr.gov.pl/pomockrajowa.html. 


\section{M. Tereszczuk}

Alternatywą dla produkcji trzody może być hodowla bydła mięsnego (An alternative to pig production may be beef cattle breeding). (2018). PAP data: 07.02.2018. Pobrano z: http://www.portalspozywczy.pl/drukuj/ 154717.html

Biuletyn Statystyczny GUS (Statistical Bulletin of the Central Statistical Office). (2018). Główny Urząd Statystyczny, 7, 142.

Charakterystyka gospodarstw rolnych w 2016 r. (Characteristics of agricultural holdings in 2016) (2017). Główny Urząd Statystyczny, Warszawa.

Eurostat (2018). Pobrano sierpień 2018 z: https://ec.europa.eu/eurostat/data/database

Główny Inspektorat Weterynarii (2018). ASF - najczęściej zadawane pytania (FAQ). Afrykański pomór świń informacje ogólne. (ASF - frequently asked questions (FAQ). African swine fever - general information). Pobrano sierpień $2018 \mathrm{z}$ : https://www.wetgiw.gov.pl/nadzor-weterynaryjny/asf.

Komunikaty Głównego Lekarza Weterynarii (GIW) o przypadkach afrykańskiego pomoru świń (ASF) na terytorium Polski (Announcements of the Chief Veterinary Officer on cases of African swine fever (ASF) on the territory of Poland). (2018). Pobrano sierpień 2018 z: https://www.wetgiw.gov.pl/main/ komunikaty/Komunikat-Glownego-Lekarza-Weterynarii-o-przypadkach-afrykanskiego-pomoru-swin-ASFna-terytorium-Polski/.

Levis, D.G., Baker, R.B. (2011). Bioasekuracja świń i ochrona fermy trzody chlewnej (Swine biosecurity and pig farm protection). University of Nebraska-Lincoln Extension, USA.

Ministerstwo Finansów (2018). Dane dotyczące wyników handlu zagranicznego mięsem wieprzowym. Pobrano sierpień 2018: https://www.gov.pl/rolnictwo/polski-handel-zagraniczny-artykulami-rolno-spozywczymi

Ministerstwo Rolnictwa i Rozwoju Wsi (2017). ASF - Afrykański Pomór Świń. (ASF - African Swine Fever). Broszura Informacyjna, Warszawa 2017. Pobrano sierpień 2018 z: https://www.gov.pl/rolnictwo/afrykanskipomor-swin.

Mroczek, R. (2018). Sektor mięsa czerwonego i drobiowego. Rozwój, wyzwania, zagrożenia (Red and poultry meat industry. Development, challenges and hazards). Przemyst Spożywczy, 72(3), 2-7.

Niemczuk, K., Pejsak, Z., Woźniakowski, G. (2018). Afrykański pomór świń (African swine fever). Państwowy Instytut Weterynaryjny - PIB, Puławy. Pobrano sierpień 2018 z: http://www.piwet.pulawy.pl/.

Pejsak, Z. (2016). Prawdopodobne konsekwencje ekonomiczne wystappienia ASF, w zależności od wielkości i gęstości populacji stad świń w regionie (Probable economic consequences of ASF, depending on the size and density of the pig population in the region). Państwowy Instytut Weterynarii - PIB, Puławy. Pobrano sierpień 2018 z: http://www.piwet.pulawy.pl/.

Szczepańska, M. (2018). Wakacje sprzyjają świńskiemu wirusowi (Holidays are conducive to the porcine virus). Puls Biznesu 02.07.2018.

Tereszczuk, M. (2015). Analiza wyników handlu zagranicznego produktami mięsnymi w 2014 roku (Analysis of the results of foreign trade in meat products in 2014). Gospodarka Mięsna, 3, 47-48.

Tereszczuk, M. (2018). Analiza wyników handlu zagranicznego produktami mięsnymi w 2017 roku (Analysis of the results of foreign trade in meat products in 2017). Gospodarka Miesna, 3, 48-52.

Winiarczyk, S., Grądzki, Z. (red.) (2002). Choroby zakaźne zwierząt domowych z elementami zoonz (Infectious diseases of domestic animals of elements zoonz). Wydawnictwo Państwowego Instytutu Weterynarii, Lublin-Puławy, 163-173.

Zawadzka, D., Pasińska, D. (2018). Aktualny i przewidywany stan rynku wieprzowiny. Rynek mięsa: stan i perspektywy, (The current and forecasted state of the pork market. Meat market: state and perspectives). IERiGŻ-PIB, KOWR, MRiRW, nr 54, 11-14.

Do cytowania / For citation:

Tereszczuk M. (2018). Rynek mięsa wieprzowego w Polsce w obliczu afrykańskiego pomoru świń (ASF). Problemy Rolnictwa Światowego, 18(3), 306-314; DOI: 10.22630/PRS.2018.18.3.88

Tereszczuk M. (2018). The Pork Market in Poland in the Face of African Swine Fever (ASF) (in Polish). Problems of World Agriculture, 18(3), 306-314; DOI: 10.22630/PRS.2018.18.3.88 